Yalova Sosyal Bilimler Dergisi

\title{
Halkla İlişkilerde Güven Kavramının Önemi
}

\author{
Begümhan GÖKTÜRK
}

\section{Özet}

Günümüzün artan rekabet koşulları altında bir organizasyonun faaliyet gösterdiği alan ne olursa olsun başarıya ulaşmak zorlu bir süreci gerektirir. Organizasyonlar, hedef kitleleri olan müşterileri ve bireyleri, etkilemek ve desteğini almak istemektedirler. Başarıya giden yolda ilk adım hedef kitleyi doğru tanımlamak ve güvenini kazanmaktır.

Genel bir çerçeveden, halkla ilişkilerin amaçlarına bakıldığında temel olarak şunlar sayılmaktadır: Hedef kitlenin ihtiyaçlarını belirlemek, kurulus hakkında kamuoyunda olumlu bir algı ve bilinirlik yaratmak, itibarı yükseltmek, güven ve destek sağlamak. İnsan ilişkileri denilince ilk akla gelen güven kavramı pek çok disiplinde tartışılan ve açıklanmaya çalışılan bir kavram olarak karşımıza çıkmaktadır. Çünkü güven bireylerin ve toplumların her türlü kararlarında en temel unsurlardan biri olarak kabul edilmektedir. Halkla ilişkilerde güven, organizasyon ve toplum arasındaki ilişkinin etik kısmını belirleyen en kritik unsurdur.

Başta müsteriler olmak üzere, bir kurumun tüm paydaşlarına karș1 taşıdı̆̆ daha kapsamlı bir sorumluluk vardır. Tüm paydaşlara karşı duyulan bu sorumluluk, güven yaratmada da ön plana çıar. Kurumsal sosyal sorumluluğun yerine getirilmesinde, paydaşların beklentilerine cevap veren ve onlarda kuruma karşı güven oluşturan bir tutum içerisinde olunması gereklidir.

Anahtar Kelimeler: Güven, Halkla İlişkiler, Kurum, İtibar, Risk

\section{The Significance of the Concept of Trust in Public Relations}

\begin{abstract}
Due to the increased competitive environment present in all types of industries, organizations are experiencing increasingly difficult periods in order to thrive. The survival of these organizations depends largely on each of their niche target markets and the support of their customers. The first step to the path to success is to gain the trust of target markets and customers and to ensure appropriate identification of the organization within the niche market.

Within the general framework, the role of public relations includes the following activities: identification of the needs and demands of the target market, creation of a positive perception of the organization and public awareness in the target market, to raise the reputation of the organization and build confidence and support within the market. The concept of people skills and relations first bring to mind the idea of trust which is discussed in many disciplines, and considered to be the deciding factor for the most basic decisions made by customers. Trust inspired by public relations between the organization and the population (market) is a crucial part of the ethical component of the relationship.

An organization is responsible to its stakeholders, primarily its customers, and in being so responsible, further creates trust between itself and its stakeholders. an organization must operate in such a way that it delivers on its social responsibilities in a way expected by its stakeholders which in turn generates more trust.
\end{abstract}

Key Words: Trust, Public Relations, Organization, Reputation, Risk

${ }^{1}$ Yrd.Doç. Dr. İstanbul Arel Üniversitesi, İletişim Fakültesi, begumhangokturk@arel.edu.tr 
Yalova Sosyal Bilimler Dergisi

\section{Giriş}

Halkla ilişkiler konusunda çalışan akademisyen ve profesyonellerin, kültürel, sosyal ve ekonomik faktörlerin halkla ilişkilerin geliştirilmesi üzerindeki etkisini daha detaylı incelemeleri gerekir (Kent ve Taylor, 2007: 18). Bu inceleme neticesinde, halkla ilişkilerin etkilendiği bu faktörlerdeki ortak hususlardan birisi olan "güven" kavramının da önemi daha iyi anlaşılabilecektir.

Rekabetin oldukça arttığı bu dönemde, her ne alanda faaliyet gösterirse göstersin, bir organizasyonun başarılı olabilmesi zor bir süreç gerektirmektedir. Hedef kitle olan müşteriler veya bireyler, organizasyonların etkilemek ve desteğini almak istedikleri unsurlardır. Günümüz ortamında bir kurumun hedef kitlesi tarafından algılanmak istediği gibi algılanmayı sağlaması gittikçe zorlaşmıştır. Bunun sağlanabilmesi için iyi bir iletişim ve etkileşim ortamının oluşturulabilmesi gereklidir. Bu noktada devreye halkla ilişkiler girer. Kitleye gönderilen mesajların içeriklerinin doğru oluşturulmasını, kurumun öne çıkarmak istediği güçlü özelliklerini etkin bir yolla iletmesini ve istenilen biçimde algılanmayı sağlamak görevi halkla ilişkilerindir. Kitleyi oluşturan her bireyin farklı bilişsel, psikolojik, sosyal ve kültürel özellikleri vardır ve mesajları bunlar temelinde algılamaktadır (Bayar, 2006: 26). Halkla ilişkilerde başarılı olunabilmesi için bu farklılıkların göz önüne alınması şarttır. Fakat hedef kitledeki bireyler birbirinden ne kadar farklı olursa olsun, güven temelinde birleşmeleri kolay olacaktır. Firma ve organizasyonun güvenilir olup olmaması ortak bir kamuoyu oluşturabilecek yeterliliktedir.

Halkla ilişkilerde hedef kitle kuşkusuz müşteridir. Müşteri memnuniyeti en çok araştırılan konulardan biridir. Hedef kitlenin davranış ve kararlarında etkili olan müşteri memnuniyetini belirleyen farklı unsurlar vardır. Hizmet kalitesi, müşteri memnuniyetinin en başta gelen belirleyicilerinden biridir. Müşterilerin sunulan hizmetten memnun olmasını sağlayan tüm fiziksel ve fiziksel olmayan unsurları içeren hizmet kalitesinin boyutları kavramı üzerine literatürde farklı boyutlardan bahsetmek mümkündür. Hizmetin literatürde en çok rastlanan beş boyutu; "güvenilirlik, fiziksel - somut varlıklar, yanıt - tepki verebilirlik, güven ve empatidir" (Canoğlu, 2008: 28). Mal ve hizmet kalitesinin özelliklerinden olan güven kavramı ilk sıralarda yer almaktadır ve şöyle ifade edilmiştir: "Güvenilirlik: Organizasyonun hizmeti zamanında ve güvenilir bir şekilde yapabilme durumu."

\section{Halkla İlişkiler Kavramına Genel Bakış}

Birçok akademisyen ve uygulayıcının belirttiği gibi, halkla ilişkiler, bir organizasyonun halkla kurup devam ettirdiği karşıllklı ve olumlu ilişkilerdir. Bununla birlikte halkla ilişkiler yazını incelendiğinde, tam bir tanım birliği ile net ve kolay anlaşılabilir bir halkla ilişkiler tanımına rastlamanın zor olduğu sıkça belirtilmektedir. Okuyucular tarafından, halkla ilişskilerin ne anlama geldiğini, bu ilişkilerle neyin kastedildiğini bildikleri kabulüne dayanan varsayım yanlış bir kabuldür (Broom, Casey ve Ritchey, 1997: 83). 
Yalova Sosyal Bilimler Dergisi

Halkla ilişkilerin genel olarak kabul görmüş net bir tanımı yapılamamış olsa da, görüş ve davranışları etkileyen bir anlayış yaratarak duyarlılık ve saygınlığa sahip çıkan ve geliştiren bir disiplin olarak kabul edilen halkla ilişkilerin şimdiye kadar çok sayıda tanımı da yapılmaya çalışııııştır. 1978 yılında Mexico City'de yapılan Birinci Dünya Halkla İlişkiler Kongresi'nde görüş birliğine varılan halkla ilişkiler tanımı, uluslararası anlamda en fazla kabul gören tanım olmuştur. Buna göre, "halkla ilişkiler çalışmaları; eğilimleri çözümleme, sonuçlarını önceden kestirme, kuruluşların liderlerine danışmanlık yapma ve hem kuruluş hem de kamu yararına planlı faaliyet programlarını uygulama sanatı ve sosyal bilimidir" (Karatepe, 2008: 78). Bu tanımın yanı sıra, yüzlerce tanım bulunmaktadır. Ancak, burada kavramın tanımlanması konusunda detaylara girilmesine gerek görülmemiştir.

Genel bir çerçeveden, halkla ilişkilerin amaçlarına bakıldığında temel olarak şunlar sayılmaktadır: Hedef kitlenin ihtiyaçlarını belirlemek, kuruluş hakkında kamuoyunda olumlu bir algı ve bilinirlik yaratmak, itibarı yükseltmek, güven ve destek sağlamak. Bu amaçlara ulaşmak bir anda olmayan, bir süreç ve belirli aşamalardan geçilmesini gerektiren bir yapıya sahiptir. Bu süreç ve aşamalar, halkla ilişkilerin sistematik bir yaklaşıma sahip olduğunu göstermektedir.

Halkla ilişkilerin öncülleri olarak, algı, dürtü, ihtiyaç ve davranış sayılabilmektedir. Bir açık sistem yaklaşımıyla, sayılan bu öncüller, halkla ilişkiler açık sisteminin girdilerini oluşturmaktadır. $\mathrm{Bu}$ öncüller, halkla ilişkilerin çevreden nasıl etkilendiğinin bir ifadesidir. Sistemin çıktıları ise, halkla ilişkilerin çevreyi etkileyen unsurlarıdır. Bu haliyle halkla ilişkilerin, bağımlı ve bağımsız bir yapı içerisinde olduğu ifade edilebilir(Broom, Casey ve Ritchey, 1997: 94).

Açık sistem yaklaşımının halkla ilişkilerin yapısının doğru ve net bir şekilde anlaşılabilmesine katkı sağlayacağı açıktır. Şekil-1'de halkla ilişkilerdeki girdisüreç-çıktı olarak değerlendirebilen sistem yaklaşımı görülmektedir (Broom, Casey ve Ritchey, 1997: 94).

Şekil 1: Organizasyon Halk İlişkisi Süreci (Öncüller Ve Sonuçlar)

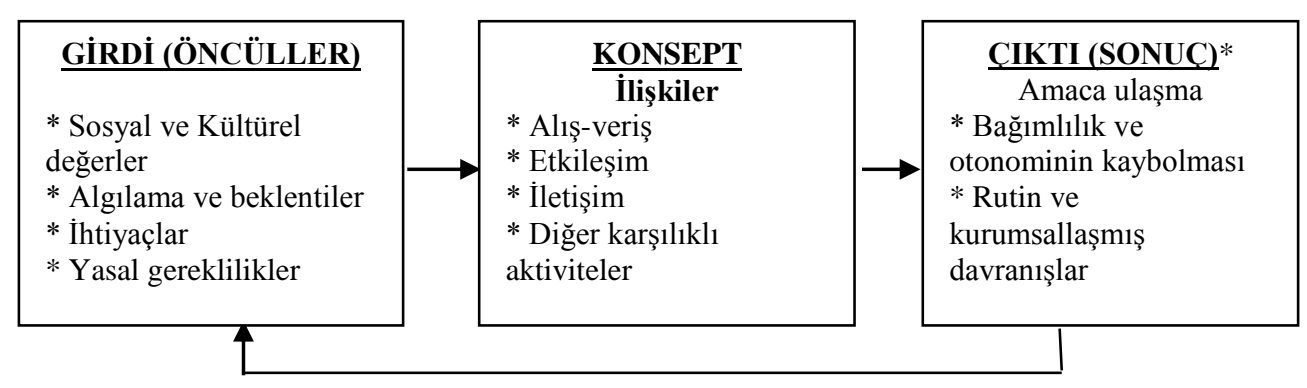

Kaynak: Broom, Casey ve Ritchey, 1997: 94.

\section{Güven Kavramı ve Tanımı}

İnsan ilişkileri ve bu ilişkilerin belirleyicisi ve etkileyicisi durumundaki faktörlerin, birçok bilim dalının ortak konusu durumunda olması kaçınılmazdır. İnsan ilişkileri denilince akla gelen ilk kavramlardan olan güven kavramının da durumu aynı 
Yalova Sosyal Bilimler Dergisi

şekildedir. Güven kavramı pek çok disiplinde tartışılan ve açıklanmaya çalışılan bir kavram olarak karşımıza çıkmaktadır. Çünkü güven bireylerin ve toplumların her türlü kararlarında en temel unsurlardan biri olarak kabul edilmektedir. Güvene dayalı olmayan bir ilişkiden, istenen çıktının elde edilebilmesi veya arzu edilen bir hedefe ulaş1labilmesinde sorun olacaktır (Kara, Sarıkaya ve Temizel, 2009: 281). Güven, iki birey ve/veya kişiler, organizasyonlar, toplum gibi birden çok bireyin oluşturduğu gruplar arasında, paylaşılan normlara ve değerlere bağlı olarak, davranışların dürüst, destekleyici ve öngörülebilir olması beklentisidir (Kent ve Taylor, 2007: 15).

Güven, iş hayatının anlamlı bir hale gelip, iş tatmininin oluşmasında da önemli bir etkiye sahiptir (Stateman, 2004: 9).

Fukuyama’ya göre güven; “...ortak normlara dayanan ve düzenli olarak, dürüst ve is birliği içeren davranışların sergilendiği bir toplulukta, diğer üyelere yönelik olarak ortaya çıkan bir beklentidir...". Bireyin topluluktaki birey veya kurumlara güven duymaması; toplumun norm ve değerleri olarak sayılan toplumsal sermayenin zayıflamasına bağlı gerçekleşmektedir (Fukuyama, 2000: 24, Aktaran: Özdemir, 2007).

Güven karmaşık bir yapılanmaya sahiptir ve genellikle ilgili disiplinlerce psikoloji, sosyoloji, ekonomi- kavramlaştırılmaktadır. Psikoloji açısından bakıldığında; kişisel deneyimler ve geçmiş sosyalleşmeden etkilenen bir kişilik ve gelişim seviyesi ya da psikolojik bir yapılaşma olarak açıklanmaktadır(Lewis \& Weigert, 1985, Aktaran: Ojha ve Gupta, [T.Y.]). Rousseau vd. psikolojik bu çerçeveyi; bağışçılar(trustors) ve güvenilir kişilerin(trustees) özellikleri açısından güvenin değerlendirilmesi olarak yorumlamaktadır. Yine Rousseau vd.'ne göre, güven kavramı sosyolojik açıdan incelenecek olursa, insanlar arasındaki ilişkilerin özelliklerine gömülü bir sosyalleşmenin içinde güvenin bulunması söz konusudur. Rousseau vd.'nin güven konusunda yaptıkları tanım ise şu şekildedir: "Güven; olumlu beklentiler ya da davranışların kabulüne açık olma niyetini içeren psikolojik bir durumdur. 'Bu tanım disiplinler aras1 bir özellik olarak açıklanmaktadır.(Rousseau et al., 1998, Aktaran:Ojha ve Gupta, [T.Y.]).

Güven, hissedilmesi kolay fakat tanımlanması zor bir kavramdır. General Electric CEO'su Jack Welch, güvenin hissedildiği zaman bilindiğini belirtmektedir. $\mathrm{Bu}$ bakış açısıyla güvenin, bir kişilik özelliği, bir sosyal ilişkiler unsuru ve örgütsel davranış kapsamında ele alındığı söylenebilir. Güven üzerine yapılan ilk çalışmalarda, başta J.B. Rotter olmak üzere, araştırmacılar güveni bir kişilik özelliği olarak görmüşlerdir. Güven bir kişilik özelliği olarak, bir kimsenin veya grubun verdiği söze başka bir kişi veya grubun itimat etmesi şeklinde belirmektedir (Rawlins, 2007:3).

Rotter ile Mayer vd.'lerine göre güven şöyle tanımlanmaktadır: "bir birey ya da grubun, bir diğer birey ya da gruba yönelik olarak sahip olduğu sözlü ya da yazılı beklentileridir" Rother'ın tanımı daha spesifik olarak nitelendirilmektedir ve psikolojide kişilik teorisini yansıtmaktadır(Rotter, 1967; Mayer et al., 1995, Aktaran:Ojha ve Gupta, [T.Y.]). Bir diğer kaynak, güven kavramını çok-disiplinli 
Yalova Sosyal Bilimler Dergisi

olarak ele almakta ve çoklu bir yaklaşım ve tanımlama ile kavramın açıklandığını belirtmektedir. Bu kaynak Rousseau vd.'nin tanımını kucaklayıc1/kapsayıcı ifade etmekte ve güvenin 3 temel boyutu olduğunu belirtmektedir. Bunlar; hayırseverlik(benevolence), yetkinlik(competence) ve dürüstlük (honesty) olarak bileşenlerine ayrılmaktadır(Grimmelikhuijsen, 2009).

Erik Erikson, insan yaşamında 8 evre belirlemiştir ve bunların her biri sosyal etkileşimde yeni bir boyut olarak açıklanmaktadır. Bu evreler şunlardır: Güvene karşı güvensizlik, özerkliğe karşı kuşku, girişkenliğe karşı suçluluk, becerikliliğe karşı aşağılık duygusu, kimlik kazanmaya karşı rol karışıklığ 1 , yakınlığa karşı yalıtılmışlık, özgeciliğe karşı kendine dönüklük, bütünlüğe karş1 umutsuzluk. Bu başlıklar arasında, çalışmamızı temel olarak ilgilendiren kavram güven olduğu için burada bu boyutun kısaca açılanması uygun görülmüştür. Güvene karşı güvensizlik bebeklik döneminde iki uca bağlı olarak oluşmaktadır. Burada bir uçta güven diğerinde güvensizlik bulunmaktadır. Sevecenliğin bulunduğu ve gereksinimlerin karşılandığı ortamlarda yetişen bebekler güven duygusunu geliştirmektedir. Tersi olarak ise bakımın yetersiz ve reddedici olduğu durumlarda, bebekte gelişiminin diğer evrelerinde de taşıyacağı dünyaya güvensizlik, korku ve kuşku tutumu gelişmektedir(Elkind, 1978).

Tanım farklılıklarına rağmen, literatürde güven;

- Yakınlıktan kaynaklanan güven

- Kişilerarası güven

- Kurumsalgüven

olarak üç grupta incelenmektedir. Yakınlıktan kaynaklanan güven; aile bağlarıyla oluşan güveni ifade etmektedir. Kişilerarası güven, modern toplumlardaki birbirlerini tanımayan ancak düzenli etkileşimde bulunan insanlar arasındaki ikincil ve daha zayıf olan ilişkilerden kaynaklanan güveni ifade etmektedir. Kurumsal güven ise günümüzün organize olmuş toplumunda, çalışanların içinde bulundukları organizasyona duydukları güveni belirtmektedir (Kara, Sarıkaya ve Temizel, 2009: 283).

Güvenin kişilik özelliği olarak incelenmesinden sonra karşımıza çıkan diğer bir unsuru ise, sosyal ilişkilerin bir parçası olarak değerlendirilmesidir. Sosyal yaklaşım, güvenin sosyal ilişkilerde gözlemlenmesi ve ölçülmesi üzerine odaklanıştır. Örneğin, M. Deutsch 1958 'de yazdığı "Güven ve şüphe" başlıklı makalesinde, güveni belirsizliği ve beklentileri etkileyen kişilerarası bir faktör olarak görmüştür (Rawlins, 2007:3). 1990’lara gelindiğinde ise, örgütsel davranış ve işletme yönetiminde değerler ve güven üzerine yapılan araştırmalar görülmeye başlanmıştır. Zand tarafından 1972'de, Golembiewski ve McConkie tarafindan 1975'deve Boss tarafindan 1978'de yapılan araştırmalarda, organizasyonlardaki yüksek güvenli grupların, düşük seviyedeki gruplara göre daha yükse performans gösterdikleri bulunmuştur. Örgütsel perspektifte güven, bir grubun diğer bir grup veya kişi hakkındaki, dürüstlüğü, kendisine yönelik hak edici olmayan bir avantaj elde etmeyeceğine dair yargısını ifade etmektedir (Rawlins, 2007:4). 
Güvenin bir diğer yönü teknoloji ile ilişkilidir. Giddens, teknoloji ile birlikte ortaya çıkan makinelerin de insanla ilişki kurulmadığı halde güvene dayalı bir temelle işlediğini açıklamaktadır. Örneğin bir ATM makinesinden ya da internetten havale yapıldığında bir insan ile yüz yüze gelinmemektedir (Giddens, 1990, Aktaran: Bourne, 2009). Hatta günümüzde havale şifresi cep telefonuna geldiğinden; makineler arası iletişime güven gibi bir kavramdan söz etmek bile olasıdır. Bu konuya da bağlı olarak, Luhmann sistemlere güven kavramından bahsetmektedir. Ona göre, belirsizlik ya da risk durumları varsa, bir sistemin -ki bu ekonomik, yasal, politik, teknik olabilir- güven içinde çalışması beklenemez. Ek olarak, Luhmann; bir sisteme güvenmenin bir bireye güvenmekten karşılaştıramaz derecede daha zor kontrol edilebilir olduğunu da belirtmiştir (Luhmann, 1988; Jalava, 2001, Aktaran: Bourne, 2009).

Luhmann'ın teorisi ile Giddens'in teorisi arasında en önemli fark şudur ki; Luhmann'a göre, güven, iletişimin bir parçası; Giddens'a göre ise bireysel sürekliliğin bir parçası olarak açıklanmaktadır. Her iki yazar güvenin bileşenlerini şu şekilde ifade etmektedir (Jalava, 2001):

\section{1-Süreklilik}

- Giddens: Güven perspektifi sürekliliğe dayalıdır.

- Luhmann: Sistem güveni süreklidir, bireysel güven yoruma ve durumlara bağlıdır.

2-Birleşme

- Giddens: Güven gizliliğin bir parçasıdır.

- Luhmann: Güven ve sistem güveni bileşenlerine ayrılmaktadır.

3-Risk İlişkileri

- Giddens: Güvenin arkasında rastgele olaylar bulunmaktadır, gizliliğin arkasında riskler bulunmaktadır, bunlar bireyleri etkiler.

- Luhmann: İnsanlar risk alırken kazançtan daha çok kayıplara önem verdiğinden güven kavramı önemli hale gelir. Belirsizliğin hâkim olduğu ve gittikçe karmaşıklaşan bir toplumda güven kavramı karmaşıklığa karşı bir çözümdür (Jalava 2001, Solomon ve Flores 2001: 22, Aktaran: Reyhanoğlu 2006: 9).

\section{Halkla İlişkiler ve Güven Kavramının Bağlantısı}

Halkla ilişkilerin tanımından da anlaşılabileceği gibi, "güven” halkla ilişkilerde çok önemli bir yeri olan ve bu yerin başka bir kavram veya unsur ile doldurulamayacağı kadar kritik bir etkisi olan temel unsurdur. Son y1llarda yönetim yazınında en çok duyulan ve araştırılan konulardan birisi olan etik ve halkla ilişkiler konusu birleştiğinde, ortaya çıkan kavram halkla ilişkilerde güven (public trust) kavramıdır. Halkla ilişkilerde güven, organizasyon ve toplum arasındaki ilişkinin etik kısmını belirleyen en kritik unsurdur (Atkin, 2003: 41).

Halkla ilişkilerde güvenin diğer bir boyutu da, organizasyon içerisinde çalışanların birbirlerine ve organizasyonlarına duydukları güvendir. Birbirine güveni olmayan 
Yalova Sosyal Bilimler Dergisi

çalışanların, halkla ilişkiler sürecinde güven tesis edebilmesi mümkün değildir. Güven dürüstlük ile başlar. Bir organizasyon ne tür bir faaliyette ve nerede olursa olsun, halkla ilişkilerdeki güveni dürüstlüğüyle sağlayabilir (Goldberg, 2002: 17). Dürüstlügü şüpheli olan bir organizasyona güven duyulmasını beklemek sadece basit bir aldanmadan öteye geçemeyecektir.

Edelman, güvenin vazgeçilmez temel bir unsur olmasına rağmen, kurumların sahip oldukları güven düzeylerini giderek kaybettiklerini açıklamaktadır. Eldeman'ın, dünyanın mevcut trendleri üzerine özellikle vurguladığı konular arasında şunlar bulunmaktadır: Hükümet yönetiminde müdahalede yükselme, kişisel mal varlıklarında kayıplar, zengin ve fakir oranlarında yükselen farklar ve adaletsizlik anlayışı, "ihtiyacımız ne" anlayışından "ne istiyoruz" anlayışına geçiş yapan bir kültür oluşumu ya da değişimi, kurum ve sözcülere güven düzeyinde düşüşler. Edelman'ın bu önemli tespitlerinin yanı sıra açıkladığı önemli istatistikler de bulunmaktadır. Edelman Trust Barometer 08'e göre, ABD'de insanların \%20 civarında bulunan bir kesimi yönetim kurulu başkanları ve hükümet yetkililerine güvenmektedir. Bir diğer ifade ile her 5 kişiden 4'ü yüksek mevkilerde bulunan insanlara inanmamaktadır. Kamuoyu liderlerinin etkileyicilikleri ve güven düzeyleri de benzer olarak düşme eğilimindedir. Bununla birlikte yine ABD'de de "bana benzeyen birine daha çok güvenirim" anlayışı \%60 oranında destek görmektedir. İnternetin hızla gelişen bir mecra olması ve ifade özgürlüğünde sınırlamaların zorlanması ve tüm sansürlere rağmen bir şekilde ortadan kalkması da önemli bir medya ve güven trendi olarak açılanmaktadır. Edelman bu konuda en etkin kanallardan biri olarak Youtube'u göstermektedir. Geleneksel basilı mecraların takibi giderek azalırken, internet haber kaynaklarının -haber siteleri, basılı mecraların online versiyonları, bloglar, sosyal ağlar vb.- takibi ise giderek artmaktadır. Bu gelişmelere ek olarak, Edelman kurum ve markalara güven konusu ile kurumsal sosyal sorumluluk arasında da bir bağ bulunduğunu ifade etmektedir (Edelman, 2008).

Türkiye'de de güven konusunda yapılan düzenli araştırmalar (örneğin Synovate ve TNS ölçümleri), kamu kurumlarına ve şirketlere olan güven düzeyinin bir düşüş eğilimi içinde olduğunu göstermektedir. Bununla birlikte, Ipsos KMG tarafından yapılan güven endekslerinde; Seda Sayan gibi alt kültürü temsil eden bir ünlü şahsiyetin yüksek güven puanları aldığı ve kendisini "güvenilir" olarak kendi programında lanse ettiği sıklıkla şahit olunmuş bir durumdur. Bu örnek, tıpkı Amerika'daki gibi "bana benzeyen birine daha çok güvenirim" anlayışının Türkiye'de de bulunduğuna dair önemli bir ipucudur. Bu eğilim ise, dünyada güven üzerine yeni bir trendin geliştiğini göstermektedir. Benzer olarak, hip-hop şarkıcılarının ve şarkılarının artışında yaşanan gelişmeler, düzene isyan ve alt kültürün öne çıkışı aynı trendin bir parçasıdır. Bu "underground- yeraltı" kültürü, kendi giyim tarzından, Kurtlar Vadisi gibi kendi sistemini kurarak ilahlaşan kültlere doğru yol almaktadır. Bu yeni yaşam tarzı da doğal olarak güven kavramını şekillendirmektedir. Bu gidişat, birçok ezilmiş grubun temsilcisi olan sanatçıların reklamlarda boy göstermesine, küresel markaların bile sesi/yüzü olmasına yol açmıştır. Bu durum elbette halkla ilişkileri de beslemekte ve gerek pazarlama yönlü halkla ilişkilerde gerek kurumsal halkla ilişkilerde çeşitli uygulamalarda kendine yer bulmaktadır. 
Yalova Sosyal Bilimler Dergisi

Güven, halkla ilişkilerdeki temel bir ilke olarak, her seviyedeki iletişimde ön plana çıkması gereken bir husustur. Gerek bir organizasyondaki tek bir çalışan ile müşteri arasındaki iletişimde, gerekse organizasyonun bir bütün olarak halkla olan iletișiminde, "güven" tesis edilmesi ve sürdürülmesi gereken önemli bir faktördür (Kent ve Taylor, 2007: 15). Profesyonellik üzerine yapılan araştırmalar göstermiştir ki, "güven" son derece büyük ve kritik bir öneme sahiptir. Bu çerçevede, meslek değerleri, profesyonellik otoritesinin temelini oluşturmaktadır. Halkla ilişkiler uzmanları, müşterilerinin ve toplumun iyiliği için profesyonellik standartlarına karşı sorumlulardır (Baker, 2002: 198, Aktaran: Bayar, 2006: 45).

Halka ilişkilerde güven, tek taraflı bir ihtiyaç ve bağımlılıktan kaynaklanmaz. Hem organizasyon hem de toplumun ihtiyacı olan bir unsur olarak karşımıza çıar. Güven temeline dayalı ilişkiler, karşılıklı bağımlılık ve bu karşılıklı bağımlılıkla erişilecek ortak amaçlara ulaşılabilmeyi sağlar (Broom, Casey ve Ritchey, 1997: 95).

Güven, etkili bir halkla ilişkiler tesis edilebilmesindeki en önemli şarttır. Güven, organizasyon ve toplum ilişkisinin kurucusu durumundadır. Özellikle yeni kurulan ve gelişmekte olan ülkelerin ekonomik kalkınmasında da güvene dayalı bir halkla ilişskilerin tesis edilmesi önemli bir husustur. Güven, halkla ilişkilere ilişkisel yaklaşımın (relational approach) temel unsurunu oluşturur. "güvenilir bulunmak", "güven oluşturmak ve yaratmak", "müşterilerin güvenini devam ettirmek" gibi konseptler, çoğu işletme kitabında bulunan ve organizasyonların halkla ilişkilerindeki temel değerlerine işret eden, güvene ilişkin konseptlerdir (Kent ve Taylor, 2007: 15).

Güven, Ballinger tarafından ortaya konulan dokuz-hücreli halkla ilişkilerdeki ilişkisel modeli açıklayan ve Tablo-1'de gösterilen modelde de temel kavram olarak değerlendirilebilir. Ballinger'in modeline göre halkla ilişkilerde güven, kendine güvenen bir algılama, açık ve net bir iletişim davranışı ve bu sürecin sonucu olarak da karşl1ıklı etkileşimi oluşturur (Ballinger, 1991, Aktaran: Broom, Casey ve Ritchey, 1997: 88).

Tablo 1: Ballinger ’in Dokuz-Hücreli Halkla İliş̧kiler Modeli

\begin{tabular}{llll}
\hline & Samimiyet & Güven & Kontrol \\
\hline Algı & Bağımlılık & İtimat & Güç \\
\hline İletişsim Davranışı & Siklık & Açıklık & Baskınlık \\
\hline İlişkisel sonuçlar & Bilgi & Karşılık vermek & Fonksiyonellik \\
\hline
\end{tabular}

Kaynak: Ballinger, 1991, Aktaran: Broom, Casey ve Ritchey, 1997: 88.

Bu modelin yanı sıra, Edelman'ın günümüz trendleri hakkındaki görüşlerine bağlı olarak, halka ilişkiler konusunda "kamusal sözleşme-public engagement"e yönelik bir geçiş olduğu vurgusu önem taşımaktadır. Kamusal sözleşmenin modeli, yatay ya da dikey düzeyde hiyerarşik olmayıp, karmaşık bağlardan oluşan dairesel bir yapılanmayı içermektedir. Kamusal sözleşmenin adımları; tanımlama, araştırma, strateji, tasarlama, yürütme ve değerlendirme olarak sıralanmaktadır. Tanımlama 
Yalova Sosyal Bilimler Dergisi

aşaması geleneksel süreçlerde olduğu gibi, hedefler ve problem kapsamını içermektedir. Araştırma aşaması, genel çevre, izleyenler/takipçiler ve paydaşlar üzerinden yapılmaktadır. Strateji aşamasında; değerler, strateji ve politika belirleme süreci gerçekleştirilmektedir. Tasarlama aşamasında, çapraz kanallarla fikirler güçlendirilmektedir. Yürütme aşamasında; medya, dijital kanallar, doğrudan kanallar ve 3.partilerle ilişkiler sağlanmaktadır. Değerlendirme aşaması ise dinleme, sürekli diyalog ve sonuçların ölçümü ana başlıklarını içermektedir (Edelman, 2008).

Şekil 2: Kamusal Sözleşme Modeli

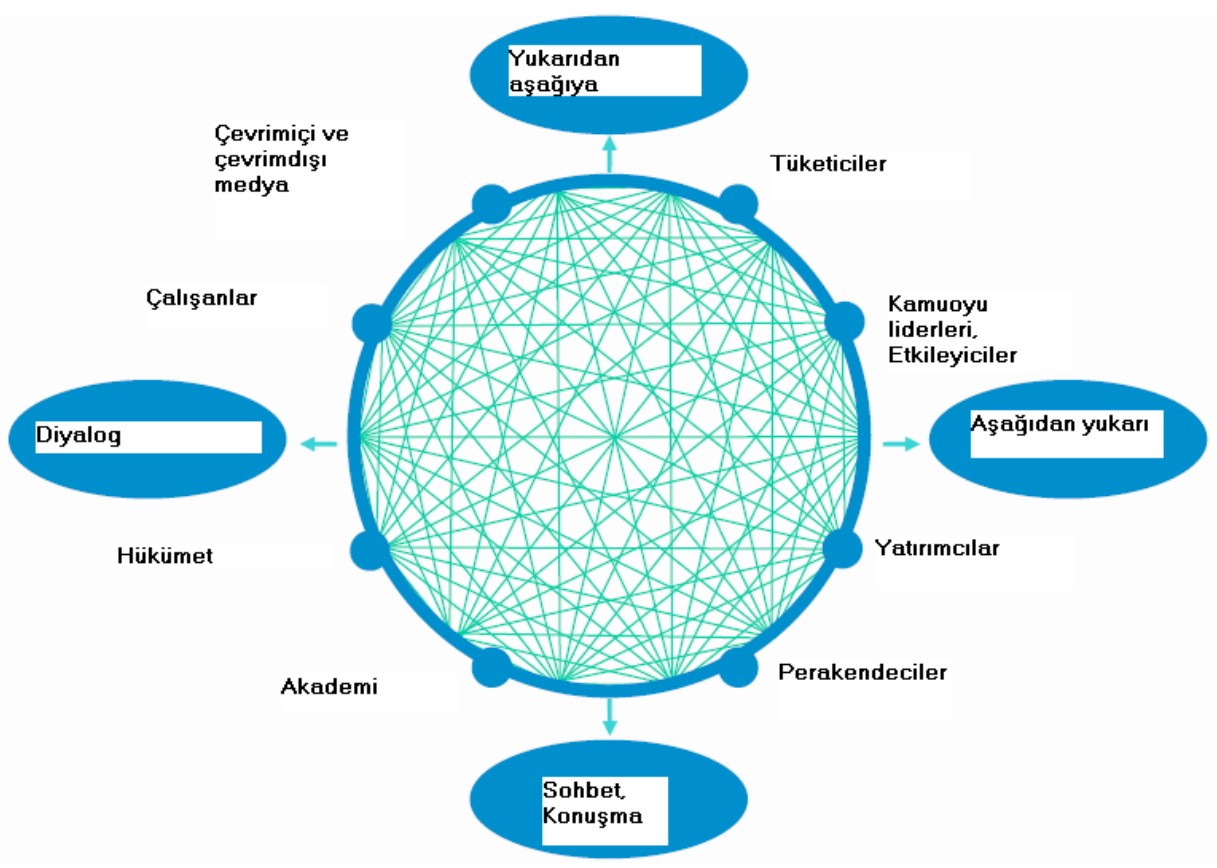

Kaynak: Edelman, 2008, s.22

Organizasyonların toplumda güven oluşturabilmek için, toplumdaki itibarlarının sağlam olması bir gerekliliktir."İtibar yönetimi, kurum ve kuruluşların öz değerlerini nasıl değerlendireceklerinden başlayıp nasıl koruyacaklarına kadar uzanan geniş bir süreci araştırmaktadır. Bu gelişmeler karşısında, örgütlerin yönetim anlayışlarında yenilikler yapmak ve itibarın tesadüflere bırakılmadan yönetilmesini sağlamak kaçınılmaz bir hal almaktadır. Temel olarak bakıldığında, itibarın özünde güven yatmaktadır" (Karatepe, 2008: 78).

Güven üzerine literatürde yazılanlar incelendiğinde de görüldüğü gibi, güven ihtiyacımız olan ve kaybetmenin kötü sonuçlara yol açacağı bir özelliktir. Güven pekiştirilerek daha ileriye götürülebilen bir özelliktir. Güven hakkındaki diğer bir özellik de, güvenin kalıcı olmadığı, yani kazanılması ve kaybedilmesi mümkün bir özellik olmasıdır. Yani, bir kere kazanılsa bile tekrar kaybedilebileceği gibi, bir kere kaybedilse bile tekrar kazanılabileceğinin bilinmesi gerekir. Bu özellikleri 
Yalova Sosyal Bilimler Dergisi

nedeniyle, güven organizasyonlarda devamlı dikkate alınması gereken ve özellikle de halkla ilişkilerde her zaman güncel ve üzerinde durulması gereken bir konu olarak değerlendirilmelidir (Rawlins, 2007:8).

Halkla ilişkilerde güvenin tesis edilip geliştirilebilmesinde yöneticilere önemli roller düşmektedir. 2002 yılında Gollin Harris tarafından yapılan bir ankette şirket CEO'larına güveni tesis etmelerine yönelik sorulara karşılık olarak alına bazı cevaplar aşağıdaki gibi olmuştur (Rawlins, 2007:3);

Bir CEO güveni tesis edebilmek için ne yapmalıdır?

- Sorumluluğu üstlenmek (\%60)

- Müssterilerle şahsen ve görülür bir şekilde ilgilenmek ve onlara ilgi göstermek $(\% 60)$

- Tüm etik değerleri titizlikle uygulamak (\%58)

- Paydaşlarla sik sik ve açık bir şekilde haberleşme içinde olmak (\%56)

- Krizleri direk, açik ve iyi bir biçimde ele almak (\%51)

Şirketler güveni tekrar nasıl tesis eder?

- İş uygulamalarında açık ve dürüst olmak (\%94)

- Direkt, açık ve etkili bir şekilde haberleşmek (\%93)

- Çalışanlara görünür bir ilgi göstermek (\%83)

Halkla ilişkilerde güvenin tesis edilip korunabilmesinde en önemli sorumluluğu üst seviye yöneticiler ve CEO'lar üstlenmişlerdir. Fakat her seviyede görev yapan yöneticiler, halkla ilişkilerde güvene dayalı bir ilişkinin tesis edilebilmesi için sorumludur. Bu sorumluluğu sadece üst seviye yöneticilerle ilişkilendirmek hatalı olacaktır. Özellikle de, misyon itibariyle organizasyonda kritik bir yeri olan orta seviye yöneticilerin tutumları, güven yaratmada da anahtar bir durumdadır (Morgan, Banch, Charles ve Robert, 1996).

Halkla ilişkilerde güvenin tesis edilmesini sadece müşterilere yönelik bir süreç olarak algılamak yanlış olacaktır. Halkla ilişkilerde güvenin tesis edilebilmesi her şeyden önce, çalışanların organizasyonlara olan güvenine bağlıdır. Çalışanlarının organizasyona güvenmediği bir organizasyonda, halkla ilişkilerde güvenden söz etmek sadece boşa harcanan bir çabadır. Bu çaba, temeli olmayan bir evin üstünü inşa etmek gibidir. Be nedenle çalışanların güvenini kazanmaya yönelik tespit ve araştırmaların da, halkla ilişkilerde güvenin kurulup geliştirilmesinde önemli bir yeri olduğu bilinmelidir. Örneğin, Rawlins (2008) tarafından örgütsel şeffaflık ve çalışanların güveni arasındaki ilişkiyi ölçmeyi hedeflediği araştırmasında, şeffaflık ve güven arasında güçlü bir ilişki bulmuştur.

\subsection{Güven Geliştirmede Bir Araç Olarak Halkla İlişsiler}

Bir organizasyonun faaliyetlerini etkili ve verimli bir şekilde yürütebilmesi için doğru bir projeye sahip olması gerekir. Yönetim sürecinde dahi, halkla ilişkilerde güvene dayalı bir iletişim içinde olunmalıdır. Kurulacak devamlı bir iletişimle, hem toplumun güveni sağlanabilecek hem de projelerde gerekli düzenleme ve 
Yalova Sosyal Bilimler Dergisi

değişimler zamanında yapılarak, ciddi bir zaman ve maliyet tasarrufu sağlanabilecektir (Mayes, 2003: 47).

Halkla ilişkilerin her adımında dürüst davranmak, araştırma ve değerlendirmede, mesajların ve programların hazırlanmasinda, planların uygulanmasinda dürüstlükten ayrılmamak başarı oranını arttırır. Dürüstlüğü onurlu çalışma, doğruluk ve güvenilirlik olarak da ayırabiliriz (Yenikurtuluş: 309). Bu değerlerin, kültür içerisinde kendini gösterdiği dikkate alınırsa, halkla ilişkilerin yerleştirilmesi ve geliştirilmesinde kültürün etkisi daha iyi anlaşılabilecektir.

Halkla ilişkilerde güven kavramının geliştirilmesinde, kültürün önemi yukarıda vurgulanmıştır. Fakat kültürün çok karmaşık bir konu olduğu dikkate alınmalı ve bu yönde yapılan çalışmaların, tek bir teoriye veya yaklaşıma bağlı kalmasının, elde edilecek bulguların yanlış değerlendirilmesine yol açabileceği unutulmamalidir (Kent ve Taylor, 2007: 18).

Halkla ilişkilerde güvenin (public trust) kazanılabilmesinde dikkat edilmesi gereken hususlar vardır. Medya ile ilişkilerin geliştirilmesi gerekir. Medyanın kamuoyu üzerindeki etkisi oldukça büyüktür. Bu etki halkla ilişkilerde güvenin geliştirilmesinde önemli bir araç olarak kullanılabilir (Goldberg, 2002: 17).

Basın özgürlüğü uzun zamandır üzerinde tartışılan bir konudur. Güven kavramı bu noktada da karşımıza çıkmaktadır çünkü medyaya karşı şeffaf olunması güveni doğrudan etkilemektedir (Tsetsura \& Luoma-aho, 2009). Bilgi akışının yansız bir şekilde sağlanması güveni artırıcı bir unsurdur.

Bentele vb. Avrupalı PR teorisyenleri, kendi dillerinde halkla ilişkilerin manasını tartmaktadır. Örneğin Almanya'da kamu ile birlikte kamu için çalışmak demektir (Bentele and Junghänel, 2004, Aktaran: Valentini, 2006). Böyle bir bakış açısı ise kamu ile birlikte ortak bir çalışmanın ortak ve çok sağlam bir güvene dayalı olacağı anlamina gelmektedir.

Halkla ilişkiler, insana odaklanan ve önceliği insana veren bir faaliyet dalıdır. İnsan ilişkilerinde vazgeçilmez bir unsur olan güven de, halkla ilişkilerin insan odaklı olmasından dolayı ön plana çıkmaktadır. Gerek kurum içi gerekse kurum dışı faaliyetlerinde kaliteyi yakalamak, özüne uygun etkinliklerde bulunmak istiyorsa bu önceliğinden asla taviz vermemelidir. Yönetimi, kurum içerisinde çalışanların tatminine, kurum dışında ise müşterilerin tatminine yönlendirmeli, yönetimle hedef kitleleri arasında karşılıklı güveni, iyi niyeti ve yakınlığı temin ederek, halkla ilişkilerde güvenin hâkim olduğu bir ortam tesis etmelidir (Akdağ ve Arklan, 2009: 190). "Günümüz iş dünyasında işletmelerin paydaşlarıyla arasında yarattığı güven, başlı başına önemli bir kaynak olmanın yanı sıra ekonomik ve sosyal başarılar için de anahtar niteliği taşımaktadır. Bunun bilincinde olan işletmeler güven kazanma adına önemli girişimlerde bulunmakta ve sürdürülebilir olmanın yollarını aramaktadır" (Kara, Sarıkaya ve Temizel, 2009: 302).

Tüm organizasyonlar huzur ve güven ortamında verimli çalışabilirler. Doğru olan halkla ilişkiler faaliyeti, karşılıklı rıza ve güven oluşturarak, organizasyon çıkarları 
Yalova Sosyal Bilimler Dergisi

ile toplum çıkarlarını dengeleyebilen bir tutum geliştirme esasına dayanmalıdır. $\mathrm{Bu}$ ise halkla ilişkilerde güvene verilen önem derecesinde sağlanabilecektir.

Müşteri memnuniyeti ve müşterilerine karş1 duyduğu sorumluluk elbette bir kurumun dikkate alması gereken çok önemli bir husustur. Fakat başta müşteriler olmak üzere, bir kurumun tüm paydaşlarına karşı taşıdığ 1 daha kapsamlı bir sorumluluk vardır. Tüm paydaşlara karşı duyulan bu sorumluluk, güven yaratmada da ön plana çıkar. Kurumsal sosyal sorumluluğun yerine getirilmesinde, paydaşların beklentilerine cevap veren ve onlarda kuruma karşı güven oluşturan bir tutum içerisinde olunması gereklidir. Kurumsal sosyal sorumluluğu paydaş yaklaşımı açısından ele alan ve paydaş beklentilerine odaklı iş görme anlayışlarını açıklayan şirket örneklerini şu şekilde vermek mümkündür (Kara, Sarıkaya ve Temizel, 2009: 302):

-Johnson \& Johnson: İlgili olduğumuz tüm taraflara adil, doğru, dürüst ve saygılı olmak işletmemizin sorumluluklarındandır.

-Shell: Hepimiz işletmemizin toplum üzerinde yaptığı etkiyi değerlendirmek ve yaptığımız her şeyin ekonomik, çevreci ve sosyal yönlerinde denge sağlamak zorundayı.

-Volkswagen: Kurumsal sosyal sorumluluğu, "bir işletmenin mevcut sorumluluklarıyla toplumun ekonomik ve sosyal sorunlarına çözümler geliştirmesi sorumluluklarını birleştirme yeteneğii" olarak tanımlar.

\section{Sonuç}

Ekonomik ve siyasi istikrarla doğru orantılı olan güven kavramı kurumların hedef kitleleri üzerinde önemli bir etki yaratmaktadır. Günümüzde de kurum ve kuruluşların hedef kitlelerine doğru ve güvenilir mesajlar ileterek kendi istedikleri algıyı yaratmaları mümkün olabilmektedir. Bunun sağlanabilmesi için iyi bir iletişim ve etkileşim ortamının oluşturulabilmesi gereklidir. $\mathrm{Bu}$ ortamın oluşmasında ise halkla ilişkilerin rolü büyüktür.

Çalışmada da ifade edildiği üzere organizasyonların toplumda güven oluşturabilmek için, toplumdaki itibarlarının sağlam olması bir gerekliliktir. $\mathrm{Bu}$ bağlamda güven kavramı da itibar kavramı gibi kazanılması güç fakat kaybedilmesi kolay bir olgu olarak karşımıza çıkmaktadır.

Bir kurumda inşa edilen güven sadece üst düzey yöneticinin uyguladığı politikayla bağlantılı olmamaktadır. Bu noktada çok boyutlu bir kavram olan kültür etkisini göstermektedir. Kurum kültürünün dürüstlüğe, şeffaflığa ve karşılıklı açık ilişkiye dayandığı organizasyonlarda güven inşasının daha sağlam temellere oturduğu gözlemlenmektedir. Bu sayede çalışanların organizasyona bağlılı̆̆ ve kurum kimliği ile birlikte kurum aidiyeti yaratmada da başarılı adımlar atılabilmektedir.

Çalışmadan ulaşılan genel sonuç; güven kavramının çok geniş tanımlandığ1 ve çok boyutlu bileşenleri bulunduğudur. Halkla ilişkiler mesleğinin temeli güvene dayalı 
Yalova Sosyal Bilimler Dergisi

ve taraflar arasında güven oluşturma esaslı olduğundan; gerek akademik çevrenin gerek pratik çevrenin bu konuya odaklanması yerinde bir davranış olacaktır. Küreselleşme ile birlikte artan yozlaşma ve güven erozyonunun önüne geçilmesinde halkla ilişkilerin önemi büyüktür. Özellikle kurumsal sosyal sorumluluk projelerine önem verilmesi ve bu kavramın gerek kurumsal güven inşa edilmesi ve kuruma itibar kazandırılması için kullanılması, gerek güven kavramının genel anlamıyla toplumda artması için kullanılması önerilmektedir.

\section{Kaynakça}

Akdağ, Mustafa; Arklan, Ümit (2009). "Toplam Kalite Yönetimi Ilkelerine Halkla İlişkiler Penceresinden Bakış", e-Journal of New World Sciences Academy (NWSA), 4(2) :175-192.

Atkin, Nigel (2003). "Ethics and PublicRelations from an Assessment Perspective".Assessment Journal, 10(1): 41-52.

Baker, Sherry (2002). "The Theoretical Ground for PublicRelations Practice and Ethics: A Koehnian Analysis”Journal of Business Ethics, 35(3) :191-205.

Bayar, Özge (2006). "Halkla İlişkiler ve Etik", Yüksek Lisans Tezi, Ankara. Erişim: acikarsiv.ankara.edu.tr/browse/1913/2579.pdf, (Temmuz, 2017).

Bourne, Clea. (2009). "Trust as a discursive process produced by financial elites:A communications perspective". Conference paper 2009 Critical Management Studies Conference University of Warwick, 13-15 July. Erişim: http://mngt.waikato.ac.nz/ejrot/cmsconference/2009/Stream24/CleaBourne.pdf, (Kasım, 2009).

Broom, Glen M., Casey Shawna ve Ritchey, James (1997). "Toward a Concept and Theory of Organization-Public Relationships” Journal of Public Relations Research, 9(2): 83-98.

Canoğlu, Meltem (2008). "Otel Müşterilerinin İmaj ve Hizmet Kalitesi Algıları ile Tekrar Satın Alma Davranışları Arasındaki İlişsinin Belirlenmesi”, Yüksek Lisans Tezi, Adana. Erişim: library.cu.edu.tr/tezler/6951.pdf, (Temmuz, 2017).

Edelman, Richard (2008). "Public Engagement: The Evolution of Public Relations". Erişim: http://www.instituteforpr.org/files/uploads/Edelman_Speech_10_29.pdf, (Kas1m, 2009).

Elkind, David (1978). “Erik Erikson: İnsanda Gelişimin 8 Evresi”. Çev. Ali Dönmez. Dialoque, Cilt 11, Sayı 1, ss.3-13. Erişim: http://dergiler.ankara.edu.tr/dergiler/40/502/6011.pdf, (Kasım, 2009).

Goldberg, Ross K. (2002). "Restoring PublicTrustIn The Health-Care System”,PublicRelations Tactics, 9(8): 7-17.

Grimmelikhuijsen, Stephan. (2009). "Transparency of local public decision-making: towards trust or demystification of government?". Erişim: http://www.egpa2009.com/documents/psg1/Grimmelikhuijsen.pdf, (Kasım, 2009).

Jalava, Janne . "Trust or Confidence?". 5th Conference of the European Sociological Association, 'Visions and Divisions', August 28 - September 1, 2001, Helsinki, Finland. Erişim: http://www.valt.helsinki.fi/staff/jjalava/trust_or_confidence.htm, (Kasım, 2009).

Kara Zişan, Sarikaya Muammer, Temizel Fatih (2009). "Yatırımcı İlişkileri Yönetiminde Güven ve Ekonomiye Etkisi”Afyon Kocatepe Üniversitesi, I.I..B.F. Dergisi 11(1): 279-307.

Karatepe, Selma (2008). "İtibar Yönetimi: Halkla İlişkilerde Güven Yaratma”Elektronik Sosyal Bilimler Dergisi, 7(23): 77-97.

Kent Michael L., Taylor Maureen (2007). "Beyond excellence: Extending the generic approach to international public relations The case of Bosnia", Public Relations Review, 33: 10-20,

Mayes, Donna Purcell (2003). "Virginia Gains Public Trust”Public Roads, 67(3): 41-47. 
Yalova Sosyal Bilimler Dergisi

Morgan, Douglas; Banch, Ron; Charle D. Cameron,; Robert Deis. (1996). "What middle managers do in local government” Public Administration Review, 56(4): 359-367.

Ojha, Amitabh ve Gupta, M. P. [T.Y.]. "Does E-Governance Enhance Trust in Government?”. Erişim:http://www.iceg.net/2007/books/3/12_413_3.pdf, (Kasım, 2009).

Özdemir, M. Çağatay. “Toplumsal Değişme Karşısında Aile ve Okul”, Türk Eğitim Bilimleri Dergisi, Bahar 2007, 5(2), 185-198.

Rawlins, Brad L. (2007) “Trust and PR Practice”, Published by the Institute for Public Relations, December.

Rawlins, Brad L. (2008) "Measuring the relationship between organizational transparency and employee trust.”,Public Relations Journal, 2(2) : 1-21.

Reyhanoğlu, Metin (2006) “Ar-Ge İşbirliklerinde Güven: Ankaradaki Teknoparklarda Faaliyet Gösteren İşletmelerde Bir Araşturma”, Doktora Tezi, Ankara. Erişim : acikarsiv.ankara.edu.tr/browse/1416/2032.pdf, (Temmuz, 2017).

Solomon, Robert C. ve Fernando Flores (2001), “Güven Yaratmak”, Çev. Ahmet Kardam, Mess Yay., İstanbul.

Stateman, Alison (2004).Harvard on Health Care: “Trust Is a Universal Driver"Public Relations Strategist, 10(2): 9-9.

Tsetsura, Katerina \& Luoma-aho, Vilma (2009). "How Much Do You Trust Me? The Role of Trust and Innovation in Russian Journalism”. Erişim:

http://www.innovationjournalism.org/ij6ac/papers/TsetsuraRussianInnovationdraft.pdf, (Kasım, 2009).

Valentini, Chiara. (2006). "The Public Relations of the European Union: New Challenges in a More Integrated Europe”. Ninth Annual International Public Relations Research Conference "Changing Roles and Functions in Public Relations" March 9-12, 2006, Miami, Florida, USA. Erişim: http://www.piar.si/fileadmin/user_upload/dokumenti/Valentini_The_Public_Relations_of_the_European_Union.pdf, (Kasim, 2009).

Yenikurtuluş, Hatice. "Üniversite Kütüphanelerinde Halkla İlişkiler Uygulaması ve Bir Örnek: İstanbul Bilgi Üniversitesi Kütüphane ve Elektronik Kaynaklar Merkezi”. Erişim: kaynak.unak.org.tr/bildiri/unak03/403-32.pdf, (Temmuz 2017). 